University of Nebraska - Lincoln

DigitalCommons@University of Nebraska - Lincoln

USDA National Wildlife Research Center - Staff Publications
U.S. Department of Agriculture: Animal and Plant Health Inspection Service

2016

\title{
Review of anthraquinone applications for pest management and agricultural crop protection
}

\author{
Shelagh T. DeLiberto \\ USDA/APHIS/WS/NationalWildlife Research Center, shelagh.t.deliberto@usda.gov \\ Scott J. Werner \\ USDA/APHIS/WS/NationalWildlife Research Center, scott.j.werner@aphis.usda.gov
}

Follow this and additional works at: https://digitalcommons.unl.edu/icwdm_usdanwrc

Part of the Life Sciences Commons

DeLiberto, Shelagh T. and Werner, Scott J., "Review of anthraquinone applications for pest management and agricultural crop protection" (2016). USDA National Wildlife Research Center - Staff Publications. 1835.

https://digitalcommons.unl.edu/icwdm_usdanwrc/1835

This Article is brought to you for free and open access by the U.S. Department of Agriculture: Animal and Plant Health Inspection Service at DigitalCommons@University of Nebraska - Lincoln. It has been accepted for inclusion in USDA National Wildlife Research Center - Staff Publications by an authorized administrator of DigitalCommons@University of Nebraska - Lincoln. 


\title{
Review of anthraquinone applications for pest management and agricultural crop protection
}

\author{
Shelagh T DeLiberto* and Scott J Werner
}

\begin{abstract}
We have reviewed published anthraquinone applications for international pest management and agricultural crop protection from 1943 to 2016. Anthraquinone (AQ) is commonly found in dyes, pigments and many plants and organisms. Avian repellent research with AQ began in the 1940s. In the context of pest management, AQ is currently used as a chemical repellent, perch deterrent, insecticide and feeding deterrent in many wild birds, and in some mammals, insects and fishes. Criteria for evaluation of effective chemical repellents include efficacy, potential for wildlife hazards, phytotoxicity and environmental persistence. As a biopesticide, AQ often meets these criteria of efficacy for the non-lethal management of agricultural depredation caused by wildlife. We summarize published applications of AQ for the protection of newly planted and maturing crops from pest birds. Conventional applications of AQ-based repellents include preplant seed treatments [e.g. corn (Zea mays L.), rice (Oryza sativa L.), sunflower (Helianthus annuus L.), wheat (Triticum spp.), millet (Panicum spp.), sorghum (Sorghum bicolor L.), pelletized feed and forest tree species] and foliar applications for rice, sunflower, lettuce (Lactuca sativa L.), turf, sugar beets (Beta vulgaris L.), soybean (Glycine max L.), sweet corn and nursery, fruit and nut crops. In addition to agricultural repellent applications, AQ has also been used to treat toxicants for the protection of non-target birds. Few studies have demonstrated $A Q$ repellency in mammals, including wild boar (Sus scrofa, L.), thirteen-lined ground squirrels (Ictidomys tridecemlineatus, Mitchill), black-tailed prairie dogs (Cyomys ludovicainus, Ord.), common voles (Microtus arvalis, Pallas), house mice (Mus musculus, L.), Tristram's jirds (Meriones tristrami, Thomas) and black rats (Rattus rattus L.). Natural sources of AQ and its derivatives have also been identified as insecticides and insect repellents. As a natural or synthetic biopesticide, $A Q$ is a promising candidate for many contexts of non-lethal and insecticidal pest management.
\end{abstract}

Published 2016. This article is a U.S. Government work and is in the public domain in the USA.

Supporting information may be found in the online version of this article.

Keywords: 9,10-anthraquinone; agricultural depredation; biopesticide; non-lethal; repellent; wildlife damage management

\section{INTRODUCTION}

\subsection{Background}

Attempts to protect agricultural crops from vertebrate and invertebrate pests date back to the beginning of agricultural systems (ca 11500 years ago). From forest gardening and subsistence farming to increased mechanization and global marketing, vertebrate and invertebrate pests have kept pace with our production efficiencies. Methods to manage agricultural pests have included myriad toxicants and non-lethal strategies (e.g. chemical, biological and physical control techniques). As early as the mid-1700s, Native Americans were using Veratrum spp. extract as a chemical repellent to protect corn seed from avian depredators.

Many natural and synthetic chemicals have been evaluated for their feeding repellency in wild birds, mammals and insects. Criteria for evaluation of effective chemical repellents include: efficacy, potential for wildlife hazard, phytotoxicity and environmental persistence. ${ }^{2}$ One substance that has been thoroughly evaluated in many pest species and application contexts is anthraquinone, or 9,10-anthraquinone (AQ).

Anthraquinone is the quinone derivative of anthracene which is commonly found in dyes, pigments and many plants and organisms. Anthraquinone refers to the diketone structure of 9,10-anthraquinone. Mass synthesis of $\mathrm{AQ}$ from anthracene, a fraction of anthracene oil obtained in the distillation of coal tar, began in the late 1800 s. $^{3}$ Synthetic forms of AQ enabled the production of AQ-based dyes in the early 1900 s.

Early repellents primarily comprised dye products that had a noxious odor or taste. ${ }^{4}$ Commonly used products included Prussian blue, red iron oxide, carbon black, coal tars and starch., ${ }^{2,4}$ The literature indicates that anthracene and $A Q$ repellent research began in the 1940s. In a review of avian repellents, Neff and Meanley $^{2}$ reported that anthracene was successfully tested with European green finches (Carduelis chloris L.) in 1941. Avery et al. ${ }^{5}$ concluded that $0.5 \%$ anthracene on rice seed (Oryza sativa L.) was the least effective repellent tested with red-winged blackbirds (Agelaius phoeniceus L.). No other repellent testing of anthracene has been published. In contrast, AQ has been extensively evaluated for pest management and agricultural crop protection.

Anthraquinone was first patented as a bird repellent in 1943. Heckmanns and Meisenheimer submitted the German patent (No. $743517)^{6}$ that fostered the first commercial formulation of an AQ-based repellent (i.e. Morkit). A subsequent US patent enabled

\footnotetext{
Correspondence to: ST DeLiberto, USDA, APHIS, Wildlife Services, National Wildlife Research Center, 4101 LaPorte Avenue, Fort Collins, CO 80521, USA. E-mail: shelagh.t.deliberto@aphis.usda.gov
}

USDA/APHIS/WS/National Wildlife Research Center, Fort Collins, CO, USA 
the importation and distribution of Morkit in the United States. ${ }^{4,7}$ Anecdotal data from Neff and Meanley ${ }^{2}$ indicate that AQ was being tested as a bird repellent around the world in the 1940s. For example, in 1948, researchers in Israel reported the protection of AQ-treated grasses and clovers from Israeli sparrows (Family: Passeridae) and larks (Family: Alaudidae), and researchers in France reported ineffective results of $A Q$ applied to corn seed. ${ }^{2}$ Anthraquinone has continued to be studied as a chemical repellent in each decade since 1940.

The mode of action of $A Q$ is to cause post-ingestional distress in birds. Several studies have described the behavior of birds following ingestion of $A Q{ }^{5,8,9}$ The emetic response is produced through irritation of the gut, but the actual mechanism is unclear. The post-ingestional distress that occurs from eating AQ-treated food results in a conditioned avoidance to that food type. . $^{5,10}$

The United Nations Economic and Social Council (UN ECOSOC) developed and adopted the Globally Harmonized System of Classification and Labelling of Chemicals (GHS) in July 2003. The GHS seeks to harmonize the major existing systems for chemicals in transport and in the workplace, pesticides and consumer products, without lowering the level of protection afforded by existing systems. Other international parties, including the European Union (EU), the Codex Alimentarius Commission (Codex) and the North American Free Trade Agreement (NAFTA), have sought to harmonize pesticide legislation by providing maximum residue limits (MRLs). ${ }^{10}$ With this rise in emphasis on MRLs, we provide a novel review of $A Q$ applications for international pest management and agricultural crop protection, including recommended concentrations based upon available testing data, from 1943 to 2016. This synthesis serves to illustrate the relevant concentrations of $A Q$ needed for various agricultural pest management needs. We have divided $A Q$ applications into four categories: avian seed treatments, avian foliar treatments, miscellaneous avian applications and non-avian applications (Tables 1 to 4). We have summarized the testing of $\mathrm{AQ}$-based products in various species, and the patents and registrations currently available for international $A Q$ applications.

\subsection{Review methods}

We have reviewed the scientific and gray literature for AQ repellent studies conducted up to and including 2016. We have searched anthraquinone, 9,10-anthraquinone, avipel, morkit and repellent, along with various combinations of bird(s), mammals, rodents, etc., using various literature search engines (AGRIS, AGRICOLA, BIOSIS, $C A B$, Google Scholar and Zoological Record). We have also utilized backward reference searching to identify and examine references in an article that related to anthraquinone. Most papers, both peer reviewed and gray literature, have been included in this review for the purposes of a complete record of species tested with AQ repellents.

\section{AVIAN SEED TREATMENTS}

Most pest management uses of $A Q$ include preplant seed treatments for the protection of newly planted crops from wild birds. Bird damage to agricultural seeds begins immediately after planting. Granivorous birds can damage pre- and post-emergent seedlings by exhuming and/or consuming the seed coat, hypocotyl and cotyledon(s). Seed treatments are used to protect pre- and post-emergent seedlings from avian depredation without negatively affecting the germination of treated seeds.

\subsection{Corn}

Corn (Zea mays L.) seed treatments have been tested with ring-necked pheasants (Phasianus colchicus L.), ${ }^{11-13}$ sandhill cranes (Grus canadensis L.), ${ }^{14,15}$ Canada geese (Branta canadensis L.) ${ }_{1}^{13}$ house crows (Corvus splendens Vieillot), ${ }^{9}$ rooks (C. frugilegus L.) ${ }^{16}$ and rock pigeons (Columba livia Gmelin), ${ }^{17}$ with varying results (supporting information Table S1). Early testing with ring-necked pheasants and AQ-treated corn had inconclusive results; none of the repellents tested, including $A Q$, reduced damage relative to untreated controls. ${ }^{11}$ Treatment concentrations were not indicated, thus prohibiting the interpretation of results. In general, recent laboratory efficacy and field experiments with ring-necked pheasants demonstrate that $A Q$ is an effective repellent for pre- and post-emergent seedlings (Table 1). ${ }^{12,13}$

Among other birds evaluated with corn seed treatments, sandhill cranes and Canada geese both demonstrated reduced consumption of corn treated with relatively low levels of $A Q .{ }^{13,14}$ Recent testing with house crows in Pakistan demonstrated a $45 \%$ reduction in consumption of corn seed treated with $10000 \mathrm{mg} \mathrm{AQ} \mathrm{kg}^{-1}$ relative to untreated corn. ${ }^{9}$ Rooks in Great Britain, however, consumed corn treated with up to $100000 \mathrm{mg} \mathrm{AQ} \mathrm{kg}^{-1}$, though corn damage was relatively low (i.e. $3.5-9.0 \%){ }^{16}$

Esther ${ }^{17}$ evaluated the repellency of corn seed treated with a plant-extracted formulation of AQ. Pigeons were offered corn seed treated with $0.16,1.6$ or $4.8 \mathrm{~mL}$ natural $A Q \mathrm{~kg}^{-1}$ and corn treated with 0.5 and $1.0 \mathrm{~mL}$ synthetic $A Q \mathrm{~kg}^{-1}$. Corn treated with $1.0 \mathrm{~mL}$ synthetic $A Q \mathrm{~kg}^{-1}$ was preferred over untreated seeds. Although significant repellency for corn treated with $4.8 \mathrm{~mL}$ natural $\mathrm{AQ} \mathrm{kg}^{-1}$ was observed on day 1, repellency was not observed on days 2 to $4 .{ }^{17}$ Previously, the repellency of $10000 \mathrm{mg} \mathrm{AQ} \mathrm{kg}^{-1}$ offered in solution in the drinking water of rock pigeon demonstrated a $50 \%$ reduction in water intake. $A Q$ is insoluble in water, which may have contributed to the lower efficacy compared with other tested compounds. ${ }^{18}$

\subsection{Rice}

Testing of rice seed treatments has largely focused on Icteridae species found in the United States, primarily red-winged blackbirds. Testing has included no-choice and choice experiments and a variety of AQ-based products. Red-winged blackbirds have consistently demonstrated repellency to AQ-treated rice seed. Repellency has been positively associated with $\mathrm{AQ}$ concentrations as low as $50 \mathrm{mg} \mathrm{AQ} \mathrm{kg}^{-1}$ and up to $20000 \mathrm{mg} \mathrm{AQ} \mathrm{kg} \mathrm{kg}^{-1}$, regardless of the tested product. ${ }^{5,13,19-25} \mathrm{~A}$ threshold concentration of $4921 \mathrm{mg} \mathrm{AQ} \mathrm{kg}^{-1}$ on rough rice was predicted for $80 \%$ repellency in red-winged blackbirds; ${ }^{13}$ this concentration also causes conditioned avoidance in investigations of sensory cues. ${ }^{23}$ Red-winged blackbirds preferred untreated rice to rice treated with $2325 \mathrm{mg}$ $\mathrm{AQ} \mathrm{kg}{ }^{-1}$ in preference testing. ${ }^{13}$ Common grackles (Quiscalus quiscula L.), boat-tailed grackles (Q. major Vieillot), great-tailed grackles (Q. mexicanus Gmelin) and brown-headed cowbirds (Molothrus ater Boddaert) have demonstrated repellency to AQ-treated rice seed at 5000-20000 mg AQ kg ${ }^{-1}$ in no-choice trials. . $^{5,19,20,22,24,26}$

Field testing of AQ-treated rice seed in water-seeded field tests in Louisiana demonstrated that rice seed treated with 7100-8800 mg AQ kg-1 at planting was effective for blackbird repellency. ${ }^{19-21,27}$ Anthraquinone-treated plots had higher plant density than control plots at the conclusion of the study, and bird activity within control plots was twice that observed within treated plots. ${ }^{19-21,27}$ Anthraquinone residues on treated rice seed decreased up to 50\% 1-3 days post-planting without affecting blackbird repellency. ${ }^{19-21,27}$ Attempts to soak rice seed with an 


\begin{tabular}{|c|c|c|c|}
\hline Crop & Species & Scientific name & Recommended concentration $\left(\mathrm{mg} \mathrm{AQ} \mathrm{kg}^{-1}\right)^{\mathrm{a}}$ \\
\hline Corn & Canada goose & Branta canadensis & 1450 \\
\hline Corn & Ring-necked pheasant & Phasianus colchicus & $\mathrm{n} / \mathrm{a}$ \\
\hline Corn & Sandhill crane & Grus canadensis & 2500 \\
\hline Corn & Rock pigeon & Columba livia & None \\
\hline Corn & House crow & Corvus splendens & 10000 \\
\hline Corn & Rook & Corvus frugilegus & None \\
\hline Rice & Dickcissel & Spiza Americana & $>5000$ \\
\hline Rice & Red-winged blackbird & Agelaius phoeniceus & 5000 \\
\hline Rice & Common grackle & Quiscalus quiscula & 20000 \\
\hline Rice & Boat-tailed grackle & Quiscalus major & 10000 \\
\hline Rice & Great-tailed grackle & Quiscalus mexicanus & 2000 \\
\hline Rice & Brown-headed cowbird & Molothrus ater & 5000 \\
\hline Sunflower, confectionary & Common grackle & Quiscalus quiscula & 9200 \\
\hline Sunflower, oilseed & Red-winged blackbird & Agelaius phoeniceus & 1994 \\
\hline Sunflower, hulled & Ring-necked pheasant & Phasianus colchicus & $>1310$ \\
\hline Sunflower, oilseed & Ring-necked pheasant & Phasianus colchicus & 15800 \\
\hline Wheat & Horned lark & Eremophila alpestris & 3010 \\
\hline Wheat & House sparrow & Passer domesticus & $800-10000$ \\
\hline Wheat & Mallard & Anas platyrhynchos & 170 \\
\hline Wheat & Ring-necked pheasant & Phasianus colchicus & Unknown \\
\hline Wheat & Rook & Corvus frugilegus & $>2250$ \\
\hline Oak spp. & Wild birds & & $3.32 \mathrm{~kg} \mathrm{ha}^{-1}$ \\
\hline Pine spp. & Wild birds & & 150000 \\
\hline Millet & Brown-headed cowbird & Molothrus ater & 5000 \\
\hline Millet & Northern bobwhite & Colinus virginianus & 1180 \\
\hline Millet & European starling & Sturnus vulgaris & 1131 \\
\hline Millet & Red-winged blackbird & Agelaius phoeniceus & $>1000$ \\
\hline Oats & Wild turkey & Meleagris gallopavo & $4000-5300$ \\
\hline Sorghum & Brown-headed cowbird & Molothrus ater & None \\
\hline CUBC $^{b}$ & European starling & Sturnus vulgaris & 33300 \\
\hline Poultry pellets & European starling & Sturnus vulgaris & $>35000$ \\
\hline Poultry feed & Chicken & Gallus gallus & 20000 \\
\hline
\end{tabular}

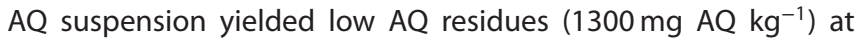
planting and no repellency to blackbirds. ${ }^{27}$ Anthraquinone was retained on drill-seeded rice up to 19 days post-planting, and residues averaged $5993 \mathrm{mg} \mathrm{AQ} \mathrm{kg}^{-1}$ during the test period. ${ }^{25}$

Internationally there has been one additional species evaluated with AQ-treated rice seeds. Rice treated with $5000 \mathrm{mg} \mathrm{AQ} \mathrm{kg}^{-1}$ reduced consumption by dickcissels (Spiza americana Gmelin) in no-choice trials, while rice treated with 500 and $1000 \mathrm{mg} \mathrm{AQ}$ $\mathrm{kg}^{-1}$ was ineffective. In choice trials, dickcissels consumed more untreated millet (Panicum spp.) than AQ-treated rice seed. ${ }^{28}$

\subsection{Sunflower}

Bird damage to sunflower (Helianthus annuus L.) is largely an issue during the ripening phase of plant growth owing to passerine damage to sunflower achenes. In addition, ground feeding birds such as ring-necked pheasants can damage newly planted sunflower fields. Testing with $A Q$ as a sunflower seed treatment has been conducted with red-winged blackbirds, common grackles and ring-necked pheasants. Red-winged blackbirds exhibited greater than $80 \%$ repellency for sunflower treated with $1994 \mathrm{mg}$
AQ $\mathrm{kg}^{-1}$ in concentration-response experiments. ${ }^{13}$ When AQ was applied to sunflower seed in combination with registered insecticides or registered fungicides, a threshold concentration of $1475 \mathrm{mg} \mathrm{AQ} \mathrm{kg}^{-1}$ was predicted to elicit $80 \%$ repellency for oilseed sunflower in blackbirds. This is the same threshold concentration as sunflower treated with $\mathrm{AQ}$ alone. ${ }^{13,29}$ When an ultraviolet visual cue was added to the $A Q$ seed treatment, synergistic repellency was observed at $200 \mathrm{mg} \mathrm{AQ} \mathrm{kg}^{-1}$ and $350 \mathrm{mg} \mathrm{AQ} \mathrm{kg}^{-1}$ (i.e. $45-115 \%$ increase in repellency). ${ }^{30}$ Interestingly, common grackle testing with AQ-treated confectionary sunflower demonstrated a much higher threshold concentration, with predicted $80 \%$ repellency at $9200 \mathrm{mg} \mathrm{AQ} \mathrm{kg}^{-1}$. 31

Ring-necked pheasant testing with $A Q$-treated sunflower hearts (i.e. hulled sunflower) demonstrated a maximum repellency of $66 \%$ at $1310 \mathrm{mg} \mathrm{AQ} \mathrm{kg}^{-1} \cdot .^{13}$ In a later study, oilseed sunflower treated with $15800 \mathrm{mg} \mathrm{AQ} \mathrm{kg}^{-1}$ was planted and allowed to sprout to seedling stage before being offered to pairs of ring-necked pheasants. Results indicated less damage to emergent seedlings from AQ seed treatments ( $12 \%$ damage) than untreated seedlings (54\% damage). ${ }^{31}$ 


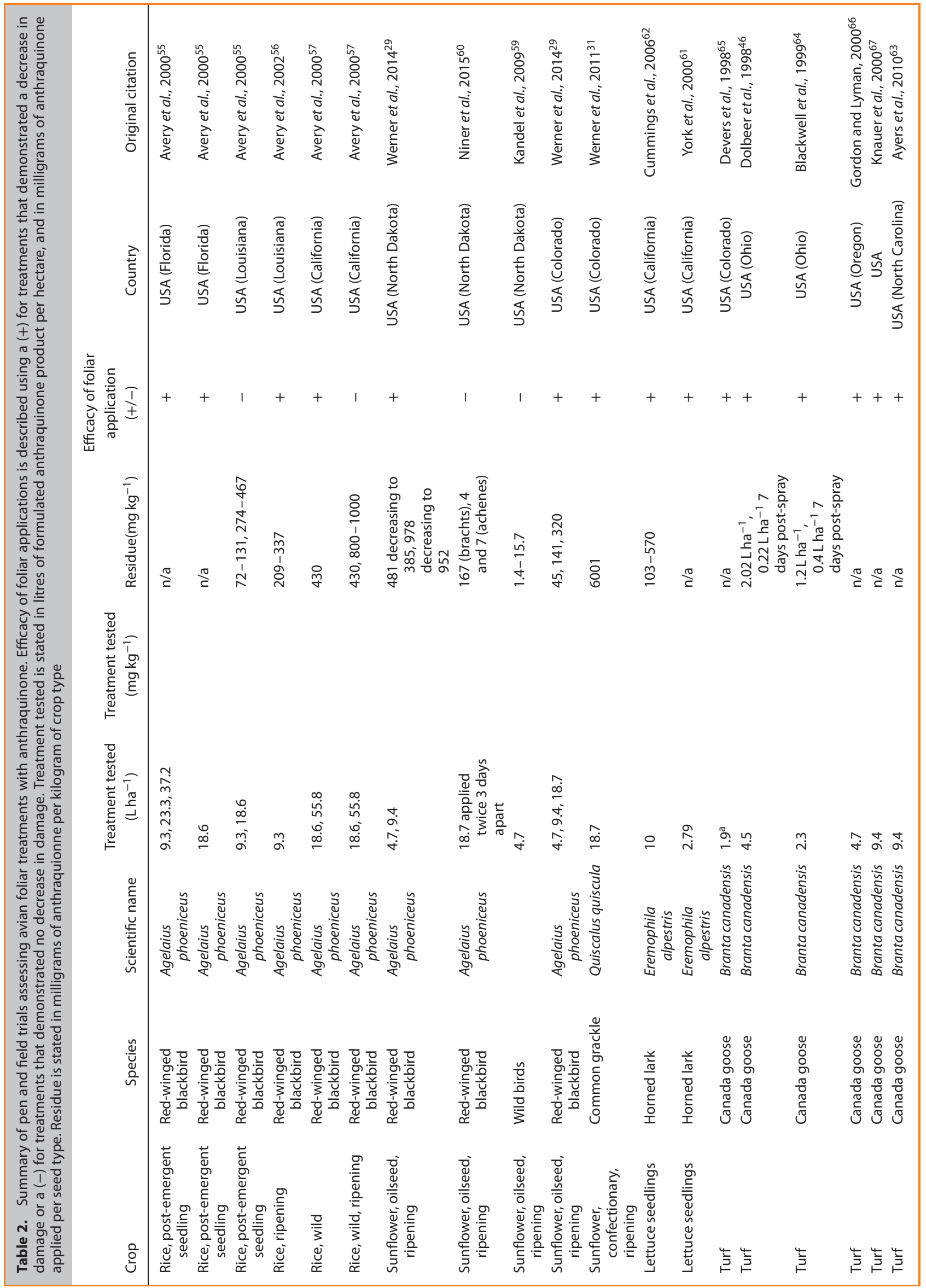




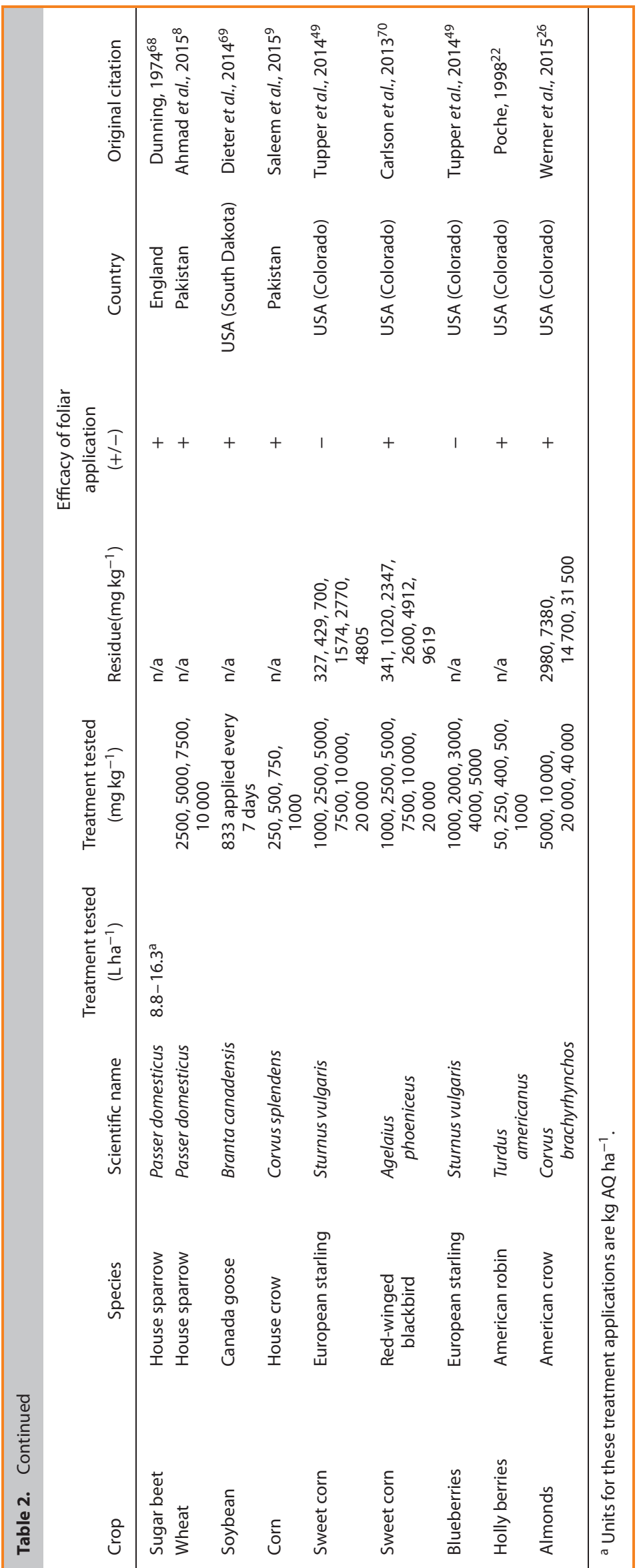


Table 3. Summary of pen and field trials assessing miscellaneous avian treatments with anthraquinone. Efficacy of miscellaneous avian treatments is described using a (+) for treatments that demonstrated a decrease in consumption or a $(-)$ for treatments that demonstrated no decrease in consumption

\begin{tabular}{|c|c|c|c|c|c|c|c|}
\hline Crop & Species & $\begin{array}{l}\text { Scientific } \\
\text { name }\end{array}$ & Application & $\begin{array}{l}\text { Treatment tested } \\
\qquad\left(\mathrm{mg} \mathrm{kg}^{-1}\right)\end{array}$ & $\begin{array}{l}\text { Efficacy of } \\
\text { application } \\
(+/-)\end{array}$ & Country & Original citation \\
\hline Granular pesticide & $\begin{array}{l}\text { Northern } \\
\text { Bobwhite }\end{array}$ & Colinus virginianus & Surface & $\begin{array}{c}1000,2000,5000 \\
8000,10000\end{array}$ & $+/-$ & USA (Colorado) & Poche, $1998^{22}$ \\
\hline Rodenticide bait & Canada Goose & Branta canadensis & Surface & $1000,10000,50000$ & + & USA (Colorado) & $\begin{array}{l}\text { Werner et al., } \\
2011^{73}\end{array}$ \\
\hline Rodenticide bait & Canada Goose & Branta canadensis & Surface & 10000,26000 & + & USA (Colorado) & $\begin{array}{l}\text { Werner et al., } \\
2011^{73}\end{array}$ \\
\hline Rodenticide bait & $\begin{array}{c}\text { Ring-necked } \\
\text { pheasant }\end{array}$ & Phasianus colchicus & Surface & 10000,20000 & + & USA (Colorado) & $\begin{array}{l}\text { Werner et al., } \\
2011^{73}\end{array}$ \\
\hline Rodenticide bait & Horned lark & Eremophila alpestris & Surface & 10000,20000 & + & USA (Colorado) & $\begin{array}{l}\text { Werner et al., } \\
\quad 2011^{73}\end{array}$ \\
\hline Toxic pest baits & Kea & Nestor notabilis & Unknown & Unknown & + & New Zealand & $\begin{array}{l}\text { Orr-Walker and } \\
\text { Roberts, } \\
2010^{79}\end{array}$ \\
\hline Toxic pest baits & Kea & Nestor notabilis & \multicolumn{2}{|c|}{ Incorporated 1000} & + & New Zealand & $\begin{array}{l}\text { Orr-Walker et al., } \\
2012^{80}\end{array}$ \\
\hline $\begin{array}{l}\text { Toxic pest baits } \\
\text { (dough/ } \\
\text { carrot) }\end{array}$ & $\begin{array}{l}\text { North Island } \\
\text { robin }\end{array}$ & $\begin{array}{l}\text { Petroica australis } \\
\text { longipes }\end{array}$ & Surface & 450,900 & + & New Zealand & $\begin{array}{l}\text { Clapperton et al., } \\
2014^{75}\end{array}$ \\
\hline Toxic pest baits & $\begin{array}{l}\text { North Island } \\
\text { robin }\end{array}$ & $\begin{array}{l}\text { Petroica australis } \\
\text { longipes }\end{array}$ & Surface & $\begin{array}{l}20000 \text { (with } \\
\text { d-pulegone) }\end{array}$ & + & New Zealand & $\begin{array}{l}\text { Day and } \\
\text { Matthews, } \\
2005^{76}\end{array}$ \\
\hline Toxic pest baits & $\begin{array}{l}\text { North Island } \\
\text { robin }\end{array}$ & $\begin{array}{l}\text { Petroica australis } \\
\text { longipes }\end{array}$ & Surface & $\begin{array}{l}10000 \text { (with } \\
\text { d-pulegone) }\end{array}$ & + & New Zealand & Day et al., $2003^{74}$ \\
\hline Structure & Rock pigeon & Columba livia & Surface & 9.4 $\mathrm{Lha}^{-1}$ & + & USA & $\begin{array}{l}\text { Knauer et al., } \\
2000^{67}\end{array}$ \\
\hline Poultry feed & Chicken & Gallus gallus & \multicolumn{2}{|c|}{$\begin{array}{r}\text { Incorporated } 15000,20000 \\
30000,70000\end{array}$} & + & USA (Florida) & $\begin{array}{l}\text { Damron and } \\
\text { Jacob, } 2001^{82}\end{array}$ \\
\hline Fruit, wild & Blackbirds & (Turdus spp.) & \multicolumn{2}{|c|}{ Incorporated Unknown } & + & England & Sorensen, $1983^{83}$ \\
\hline Chrysomelid larvae & Tits & Parus spp. & \multicolumn{2}{|c|}{ Incorporated 400, 600} & + & Germany & $\begin{array}{l}\text { Hilker and Kopf, } \\
1994^{84}\end{array}$ \\
\hline
\end{tabular}

\subsection{Wheat}

As mentioned previously, Heckmanns and Meisenheimer submitted supporting experiments to the US Patent Office in 1944. There were two experiments with crows: (1) cage testing of a mixture of $250000 \mathrm{mg} \mathrm{AQ} \mathrm{kg}^{-1}$ and $750000 \mathrm{mg}$ talcum $\mathrm{kg}^{-1}$ on wheat (Triticum spp.) seed; (2) post-emergent wheat seed treatment of $250000-100000 \mathrm{mg} \mathrm{AQ} \mathrm{kg}^{-1}$ mixed with varying levels of talcum. Both of these experiments demonstrated crow repellency and no negative effects to wheat germination. ${ }^{4,6} \mathrm{~A}$ more recent study demonstrated minimal repellency among rooks offered post-emergent wheat seedlings from $2250 \mathrm{mg} \mathrm{AQ} \mathrm{kg}^{-1}$ seed treatments (label rate). Rooks plucked seeds prior to germination and otherwise ate only above-ground phytomass. Plant density relative to the control was marginally improved. ${ }^{32}$

Among other birds evaluated with wheat seed treatments, mallards (Anas platyrhynchos L.) and horned larks (Eremophila alpestris L.) both demonstrated reduced consumption of wheat treated with relatively low levels of $A Q .{ }^{26,33}$ Pheasants were effectively repelled by unknown concentrations of five commercially available AQ-based wheat seed treatments. ${ }^{34}$ Recent testing in New Zealand demonstrated varying repellency of house sparrows (Passer domesticus L.) to wheat treated with 323-860 $\mathrm{mg} \mathrm{AQ} \mathrm{kg}^{-1}$; AQ-treated wheat was consumed less than untreated wheat in each test. ${ }^{35,36}$ Testing with house sparrows in Pakistan at higher AQ levels (2500-10000 mg AQ kg-1) demonstrated up to an $80 \%$ reduction in consumption of wheat seed treated with $A Q$ relative to untreated wheat. ${ }^{8}$

\subsection{Direct seeding of forest tree species}

Historically, AQ has been registered for the protection of forest tree seed, including longleaf pine (Pinus palustris Mill.), Eastern white pine (P. strobus L.) and oak (Quercus spp.), from wild birds. ${ }^{37-40}$ Anthraquinone seed treatments have also been used in reforestation as a bird damage prevention method for black pine ( $P$. nigra, Arnold), shortleaf pine (P. echinata, Mill.) and loblolly pine ( $P$. taeda L.) in Europe and the United States as recently as 2005. ${ }^{41-44}$ Defauce and Enriquez ${ }^{45}$ successfully tested $A Q$ seed treatments to protect pine and eucalyptus (Eucalyptus spp.) seeds from wild birds in Spain.

\subsection{Miscellaneous seed treatments}

The repellency of AQ-based seed treatments for millet has been tested with four bird species: red-winged blackbirds, brown-headed cowbirds, European starlings (Sturnus vulgaris L.) and Northern bobwhite quail (Colinus virginianus L.). Red-winged blackbirds exhibited moderate (approximately 69\%) repellency for $500-1000 \mathrm{mg} \mathrm{AQ} \mathrm{kg}^{-1}$ treated millet. ${ }^{22}$ European starlings and Northern bobwhite quail exhibited $90 \%$ repellency for millet treated with 1131 and $1180 \mathrm{mg} \mathrm{AQ} \mathrm{kg}^{-1}$ in cage testing. ${ }^{22}$ 
Table 4. Summary of pen and field trials assessing non-avian treatments with anthraquinone. Efficacy of non-avian treatments with anthraquinone is described using a (+) for treatments that demonstrated a decrease in damage or a $(-)$ for treatments that demonstrated no decrease in damage

\begin{tabular}{|c|c|c|c|c|c|c|}
\hline Crop & Species & Scientific name & Application & $\begin{array}{l}\text { Treatment tested } \\
\qquad\left(\mathrm{mg} \mathrm{kg}^{-1}\right)\end{array}$ & $\begin{array}{l}\text { Efficacy of } \\
\text { application } \\
(+/-)\end{array}$ & Original citation \\
\hline Corn & Wild boar & Sus scrofa & Seed & 8000 & + & Santilli et al., $2005^{89}$ \\
\hline Loblolly pine & Deer mouse & $\begin{array}{l}\text { Peromyscus } \\
\text { maniculatus }\end{array}$ & Seed & $\begin{array}{l}150000 \text { (with } 20000 \\
\text { Endrin } 25 \mathrm{~W} \text { ) }\end{array}$ & - & $\begin{array}{l}\text { Langdon and } \\
\quad \text { LeGrande, } 1965^{90}\end{array}$ \\
\hline Corn & $\begin{array}{l}\text { Thirteen-lined } \\
\text { ground squirrel }\end{array}$ & $\begin{array}{l}\text { Spermophilus } \\
\text { tridecemlineatus }\end{array}$ & Seed & 4826 & - & $\begin{array}{l}\text { Hodne-Fischer, } \\
2009^{12}\end{array}$ \\
\hline Corn & $\begin{array}{l}\text { Black-tailed } \\
\text { prairie dog }\end{array}$ & Cynomys ludovicianus & Seed & $\begin{array}{l}5000,10000,20000 \\
\quad 40000\end{array}$ & + & Werner et al., $2011^{73}$ \\
\hline Wheat & Common vole & Microtus arvalis & Odor & 50000 & + & $\begin{array}{l}\text { Hansen et al., } \\
2015^{92,94}\end{array}$ \\
\hline Wheat & Common vole & Microtus arvalis & Odor & 150000 & - & Hansen et al., $2016^{93}$ \\
\hline Wheat & House mouse & Mus musculus & Odor & 50000 & - & $\begin{array}{l}\text { Hansen et al., } \\
2015^{92,94}\end{array}$ \\
\hline Wheat & House mouse & Mus musculus & Odor & 150000 & - & Hansen et al., $2016^{93}$ \\
\hline Carrot & Pocket gopher & Thmomys bottae, & Seed & Unknown & - & Hansen et al., $2015^{94}$ \\
\hline Barley & Gunther's vole & Microtus guntheri & Seed & Unknown & - & Hansen et al., $2015^{94}$ \\
\hline Barley & Tristram's jird's & Meriones tristrami & Seed & Unknown & + & Hansen et al., $2015^{94}$ \\
\hline Cereal pellet bait & Roof rat & Rattus rattus & Incorporated & $\begin{array}{l}1000,2500 \text { (with } 1080 \\
\text { rodenticide) }\end{array}$ & + & Cowan et al., $2015^{96}$ \\
\hline Cereal pellet bait & Roof rat & Rattus rattus & Incorporated & $\begin{array}{l}1000 \text { (with } 1080 \\
\text { rodenticide, } 1700 \\
\text { d-pulegone and green } \\
\text { dye) }\end{array}$ & + & Crowell et al., $2016^{97}$ \\
\hline Cereal pellet bait & $\begin{array}{l}\text { Brush-tailed } \\
\text { possum }\end{array}$ & Trichosurus vulpecula & Incorporated & $\begin{array}{l}1000,2500 \text { (with } 1080 \\
\text { rodenticide) }\end{array}$ & - & Cowan et al., $2015^{96}$ \\
\hline Cereal pellet bait & $\begin{array}{l}\text { Brush-tailed } \\
\text { possum }\end{array}$ & Trichosurus vulpecula & Incorporated & $\begin{array}{l}1000 \text { (with } 1080 \\
\text { rodenticide, } 1700 \\
\text { d-pulegone and green } \\
\text { dye) }\end{array}$ & - & Crowell et al., $2016^{97}$ \\
\hline
\end{tabular}

Brown-headed cowbirds needed $5000 \mathrm{mg} \mathrm{AQ} \mathrm{kg}^{-1}$ for sustained repellency, although lower concentrations were also repellent. ${ }^{46}$

There have been few tests of $A Q$ repellency in gallinaceous birds. Two experiments evaluated the repellency of AQ-treated whole oats (Avena sativa L.) with wild turkeys (Meleagris gallopavo L.). Results predicted $80 \%$ repellency at 4000 and $5300 \mathrm{mg} \mathrm{AQ} \mathrm{kg}^{-1}$ in male and female wild turkeys respectively. ${ }^{47}$

Although previous tests with brown-headed cowbirds have indicated AQ repellency among various seeds, sorghum (Sorghum bicolor L.) seed treatments including 5000 and $10000 \mathrm{mg} \mathrm{AQ} \mathrm{kg}^{-1}$ provided no repellency within Oklahoma fields. Cowbirds consumed all of the AQ-treated sorghum during the field study. The authors suggested that the AQ sourced for this test may have been old and therefore may have lost its repellency. ${ }^{48}$

Two experiments conducted with European starlings utilized pelletized baits to determine threshold repellency. One experiment utilized poultry pellets with $\mathrm{AQ}$ incorporated into the pellet mix prior to formation of pellets. Even at concentrations up to $35000 \mathrm{mg} \mathrm{AQ} \mathrm{kg}{ }^{-1}$, only $77 \%$ repellency was observed. ${ }^{49}$ European starling tests utilizing $\mathrm{CU}$ bird carrier, a high-protein and high-fat feed, predicted $80 \%$ repellency at $6275 \mathrm{mg} \mathrm{AQ} \mathrm{kg} \mathrm{kg}^{-1} .4$ The formulation of the $A Q$ treatment (i.e. homogeneous baits versus surface application) can therefore influence repellent efficacy.

\subsection{Discussion}

Anthraquinone seed treatments have been shown to protect preand post-emergent seedlings from depredation in laboratory efficacy experiments with a variety of avian species. This review highlights the variability in concentrations of $A Q$ needed to protect seeds from different avian species and even within species to protect various seed types. Red-winged blackbirds demonstrated greater than $80 \%$ repellency to sunflower treated with $1700 \mathrm{mg} \mathrm{AQ}$ $\mathrm{kg}^{-1}$, whereas common grackles required $12200 \mathrm{mg} \mathrm{AQ} \mathrm{kg}^{-1} \cdot 29,31$ Red-winged blackbirds demonstrated $79 \%$ repellency to $4921 \mathrm{mg}$ $\mathrm{AQ} \mathrm{kg}^{-1}$ treated rice seed, several thousand $\mathrm{mg} \mathrm{kg}^{-1}$ more than needed for sunflower. ${ }^{13}$ These results still require field validation as recommended laboratory concentrations are transitioned to use in field settings. For example, environmental conditions (i.e. irrigation, planting methods) will affect how $A Q$ is retained on seeds. Field tests of AQ-treated rice had varying results, depending on whether the rice seed was drill seeded or water seeded. ${ }^{25,27}$ Another factor affecting transition of laboratory efficacy concentrations to field settings is how birds forage. Laboratory efficacy studies with Canada geese demonstrated repellency to AQ-treated corn seed; however, geese feed by grazing and would not have contact with the treated seed once planted. Species-specific laboratory efficacy experiments and field residue studies are recommended at AQ concentrations sufficient for the protection of preand post-emergent seedlings from avian depredation. ${ }^{50}$

Anthraquinone is not toxic to red-winged blackbirds or European starlings at $100 \mathrm{mg} \mathrm{kg}^{-1} .^{51,52}$ There have been no reported 
avian or mammalian mortalities related to the ingestion of preor post-emergent seedlings from $A Q$ seed treatments, thus indicating limited wildlife hazard. ${ }^{22}$ Testing has also demonstrated a lack of acute toxicity in crayfish (Procambarus clarkii Girard) associated with $\mathrm{AQ}$ treatments within rice-crayfish crop rotations. ${ }^{53}$ Anthraquinone has been shown to have negligible effects on the germination of various agricultural crop seeds. ${ }^{17,21,31}$ Sunflower seed treatments comprising $A Q$ and a registered fungicide or $A Q$ and a registered insecticide demonstrated no decrease in avian repellency or seed germination. ${ }^{29}$ Moreover, $A Q$ residues from $10000 \mathrm{mg} \mathrm{AQ} \mathrm{kg}^{-1}$ rice seed treatment were $0.1 \mathrm{mg} \mathrm{AQ} \mathrm{kg}^{-1}$ at harvest. ${ }^{25}$

Based upon the promising repellency of AQ seed treatments, several patents have been filed subsequent to the original German patent in 1943 (German Patent No. 743517). ${ }^{6}$ A patent was filed in each of the United Kingdom (GB1601226; 1981), Japan (JP62-43961; 1987) and the United States (US005885604; 1999)..$^{54}$ All three of these patents described the use of AQ for the protection of seeds from birds, and in some cases have led to the registration of products for the protection of seeds from birds (supporting information Table S3).

\section{AVIAN FOLIAR TREATMENTS}

Foliar treatments are applied directly to emergent seedlings and to maturing and preharvest crops via ground or aerial spray applications. Foliar pesticide applications are most commonly used for the application of insecticides, fungicides, herbicides and molluscicides on agricultural crops. Herbivorous birds can damage emergent seedlings and above-ground phytomass. Granivorous birds can damage maturing seeds prior to harvest. Foliar applications have demonstrated some success in cage testing, but the efficacy of foliar repellent applications is often limited by insufficient repellent residues on the surface used by wild birds. The use of $A Q$ as a foliar treatment is not as widely found in the literature as seed treatments. Anthraquinone-based repellents have been tested in foliar applications for the protection of emergent seedlings and maturing and preharvest agricultural crops (Table 2).

\subsection{Rice}

Several studies have evaluated foliar applications of AQ to prevent rice damage by blackbirds. Presoaked rice seed that was hand sprayed post-planting with greater than $18.6 \mathrm{~L} \mathrm{ha}^{-1}$ of a formulated $\mathrm{AQ}$ product $(50 \% \mathrm{AQ})$ repelled red-winged blackbirds from small test plots $\left(300 \mathrm{~m}^{2}\right)$. However, a field test of this method utilizing two 5 ha fields aerially water seeded with rice was not successful at 9.3 and $18.6 \mathrm{~L} \mathrm{ha}^{-1}$ of an aerially applied formulated AQ product. ${ }^{55}$ Anthraquinone residues on treated rice seedlings from the field trial ranged from 72 to $131 \mathrm{mg} \mathrm{AQ} \mathrm{kg}^{-1}$ and from 274 to $467 \mathrm{mg} \mathrm{AQ} \mathrm{kg}^{-1}$ at $1 \mathrm{~h}$ post-spray and were thus insufficient for avian repellency. ${ }^{55} \mathrm{~A}$ field trial conducted in Louisiana using 18.7 $\mathrm{L} \mathrm{ha}^{-1}$ of a formulated AQ product ( $50 \% \mathrm{AQ}$ ) aerially applied on a 4 ha ripening rice field decreased bird activity in the treated plot by $80 \%$ in the first $24 \mathrm{~h}$ and resulted in complete blackbird abandonment after day 2 . Anthraquinone residues on rice panicles averaged $337 \mathrm{mg} \mathrm{AQ} \mathrm{kg}^{-1}$ upon application and declined to $209 \mathrm{mg} \mathrm{AQ} \mathrm{kg}^{-1} 14$ days post-treatment. ${ }^{56}$

Wild rice (Zizania palustris L.) is grown in California and Minnesota. Ripening wild rice treated with 18.6 and $55.8 \mathrm{~L} \mathrm{ha}^{-1}$ of a formulated $\mathrm{AQ}$ product ( $50 \% \mathrm{AQ}$ ) was ineffective at preventing damage from blackbirds, despite residues of $430-1000 \mathrm{mg} \mathrm{AQ} \mathrm{kg}^{-1}$.
Large numbers of blackbirds remained in wild rice fields, despite the AQ concentrations associated with this study. ${ }^{57}$

\subsection{Sunflower}

More than $75 \%$ of annual blackbird damage to ripening sunflower occurs within the first 18 days after flowering. ${ }^{58}$ Field enclosure experiments demonstrated lower damage and higher yield of oilseed and confectionery sunflower that were hand sprayed with 4.7 and $9.4 \mathrm{Lha}^{-1}$ of a formulated $\mathrm{AQ}$ product $(50 \% \mathrm{AQ}$ ) for red-winged blackbirds and common grackles respectively. ${ }^{29,31}$ The backs of mature sunflower heads were hand sprayed with 4.7-18.7 $\mathrm{Lha}^{-1}$ of a formulated AQ product (50\% AQ) in cage testing with red-winged blackbirds. Results demonstrated less damage among blackbirds exposed to sunflower heads treated with $18.7 \mathrm{~L} \mathrm{ha}^{-1}$ of the formulated product (i.e. $320 \mathrm{mg} \mathrm{AQ} \mathrm{kg}^{-1}$ residues on treated sunflower achenes) compared with untreated sunflower heads. ${ }^{29}$ Ground applications of an AQ-based repellent (50\% AQ) on ripening sunflower at 9.4 and $37.4 \mathrm{~L} \mathrm{ha}^{-1}$ have failed to deliver sufficient $A Q$ residues on sunflower heads for adequate prevention of bird damage. ${ }^{59,60}$

\subsection{Lettuce}

Enclosure trials of an AQ-based formulation (50\% AQ) sprayed on lettuce (Lactuca sativa L.) seedlings at $2.79 \mathrm{~kg} \mathrm{ha}^{-1}$ did not prevent damage from horned larks (i.e. $60 \%$ damage was observed). ${ }^{61}$ An AQ-based formulation ( $50 \% \mathrm{AQ}$ ) sprayed on lettuce seedlings at $10 \mathrm{~L} \mathrm{ha}^{-1}$ effectively repelled horned larks within experimental enclosures (i.e. $8.5 \%$ damage within treated and $68 \%$ damage within untreated enclosures). ${ }^{62}$ However, in a field test of three 1.2 ha test sites sprayed with $10 \mathrm{~L} \mathrm{ha}^{-1}$ of an $\mathrm{AQ}$-based formulation (50\% AQ), differences between treated and untreated plots were inconclusive owing to low bird abundance. ${ }^{62}$

\subsection{Turf}

Numerous studies have demonstrated the effectiveness of $A Q$ for the reduction of goose damage to turf grasses. ${ }^{46,63-67}$ Application rates from 4.7 to $9.3 \mathrm{~L} \mathrm{ha}^{-1}$ of an AQ-based product ( $50 \% \mathrm{AQ}$ ) yielded chemical residues of $0.22-0.4 \mathrm{~kg} \mathrm{ha}^{-1} 7$ days post-application. ${ }^{46,64}$ Thus, AQ applications have been particularly useful for airports to reduce goose-aircraft strike hazards. ${ }^{67}$

\subsection{Miscellaneous foliar applications}

Single trials of $A Q$ as a foliar treatment for seedlings have been conducted with sugar beets (Beta vulgaris L.), wheat, soybeans (Glycine $\max$ L.) and corn. Sugar beet seedlings sprayed at 8.8-16.3 kg AQ $\mathrm{ha}^{-1}$ demonstrated no significant decrease in grazing damage by house sparrows. ${ }^{68}$ Recent testing in Pakistan of wheat and corn

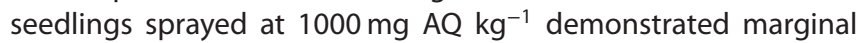
decreases in grazing damage by house sparrows and house crows respectively.,9 However, foliar applications of $A Q$ on soybeans demonstrated promising repellency against Canada geese. ${ }^{69}$

Sweet corn is a high-value commodity that is difficult to protect owing to the husk surrounding the corn kernels. Cage testing demonstrated a positive concentration-response relationship for red-winged blackbirds offered sweet corn treated with 341-9619 mg AQ kg ${ }^{-1} .^{70}$ European starlings offered sweet corn

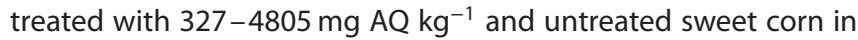
a choice test within cages ate similar amounts of AQ-treated and untreated sweet corn as concentration increased. Whereas birds repelled by anthraquinone would typically increase untreated 
corn consumption, starlings ate less overall, potentially owing to the high sucrose concentration in sweet corn and starlings' inability to process sucrose. ${ }^{49}$

Novel uses for $A Q$ as a foliar treatment have also been evaluated. Defauce and Enriquez ${ }^{45}$ described foliar applications of $A Q$ to protect branches and buds of young trees in nurseries. This idea has been extended to the potential protection of ripening fruit. Anthraquinone is registered for use in Uruguay as a bird repellent for grapes. ${ }^{71}$ Cage testing of American robins (Turdus migratorius, L.) with holly berries (Ilex spp.) treated with AQ showed modest results (33.5-69.7\% repellency). ${ }^{22}$ In European starling cage testing with blueberries (Vaccinium spp.), $5000 \mathrm{mg} \mathrm{AQ} \mathrm{kg}^{-1}$ was not sufficient to deter feeding, although untreated blueberries were preferred over blueberries treated with $2500 \mathrm{mg} \mathrm{AQ} \mathrm{kg}^{-1}$ in choice tests. ${ }^{49}$ An additional foliar application of $A Q$ involves protection of nut crops from crow damage. Anthraquinone-treated raw almonds were evaluated in cage testing with American crows (Corvus brachyrhynchos Brehm) to determine the concentration-response relationship. These experiments demonstrated that $5200 \mathrm{mg} \mathrm{AQ}$ $\mathrm{kg}^{-1}$ is needed to repel American crows from treated almonds. ${ }^{26}$

\subsection{Discussion}

Foliar applications of $A Q$ for ripening crops are limited by the methods currently available for applying chemical repellents to emergent and ripening crops. Small-scale field testing of foliar applications applied using hand-held spray equipment (i.e. backpack sprayers) has demonstrated repellent efficacy in rice ${ }^{55}$ and sunflower. ${ }^{29}$ But larger-scale field testing of foliar applications applied using aerial-spray or ground-spraying methods (i.e. tractor based) in rice and sunflower has failed reliably to provide blackbird repellency. ${ }^{56,60}$ More effective application methods for treating ripening crops with $\mathrm{AQ}$ repellents are needed. In addition, methods to reduce the amount of $A Q$ required for repellency of ripening crops are also needed. A study has demonstrated the synergistic effect of an ultraviolet feeding cue with AQ-based repellents. ${ }^{30,72}$ A patent related to this synergistic application strategy (US Patent No. 9131678 B1) involves the use of visual cues that exhibit spectral characteristics sufficiently similar to the repellent so as to reduce the amount of $A Q$ needed for avian repellency. ${ }^{72}$ This ultraviolet strategy for avian repellency may enable the registration and commercial development of AQ-based products for foliar applications and the protection of emergent and ripening agricultural crops at decreased AQ concentrations.

\section{MISCELLANEOUS AVIAN APPLICATIONS}

In addition to plant protection, $\mathrm{AQ}$ has been found to protect non-target birds from accidental poisoning and to deter wild birds from perching in unwanted places (Table 3 ). In cage testing of Northern bobwhite quail, Poche ${ }^{22}$ determined that AQ-treated granular pesticides successfully protected quail chicks from mortality. Testing to protect non-target bird species, including Canada geese, ring-necked pheasants and horned larks, indicated that AQ-treated rodenticide baits prevented consumption of $20000 \mathrm{mg}$ zinc phosphide $\mathrm{kg}^{-1}$ baits. ${ }^{73}$ Further testing of AQ-treated toxic pest baits has been conducted in New Zealand ${ }^{74,75}$ to protect the endangered North Island robins (Petroica longipes, Garnot). Day and Matthews ${ }^{76}$ applied for both international and US patents based upon these data. Later risk assessments of aerially applied toxic pest baits demonstrated that kea (Nestor notabilis, Gould), an endemic New Zealand mountain parrot, was potentially at risk. ${ }^{77,78}$ Captive testing of kea and tomtits (Petroica macrocephala) has shown promise for the use of $\mathrm{AQ}$ to prevent consumption of toxic pest baits by endemic New Zealand bird species. ${ }^{75-81}$

Flocks of birds on structures such as docks or eaves of industrial buildings can also cause damage through fecal contamination. Knauer et al. ${ }^{67}$ described the successful use of $A Q$ as an avian perch deterrent for European starlings at a metropolitan airport.

Natural sources of $\mathrm{AQ}$ have been identified for their behavioral modifications in wild birds. The seeds of common weeds, including sicklepod (Senna obtusifolia, L.) and coffee senna (Cassia occidentalis, L.), can contaminate the feed of domestic animals. These seeds contain sufficient concentrations of AQ to be toxic to poultry. ${ }^{82}$ Blackbirds (Turdus spp.) avoid buckthorn fruits, presumably owing to their emodin content (an AQ derivative). ${ }^{83}$ Similarly, Hilker and Kopf ${ }^{84}$ observed that tits (Parus spp.) significantly avoided larvae that contained 1,8-dihydroxlated 9,10-anthraquinone.

\subsection{Discussion}

Several studies have demonstrated the efficacy of AQ for the protection of non-target birds from mortality owing to consumption of toxic pest baits or rodenticide baits. Additional research is needed to develop species-specific pest baits, including AQ applications, for the protection of non-target species that exhibit AQ repellency relative to target species. There is a patent application in the United States (No. EP20030733670) and an international patent (WS 2004/000014 A1) for a bird repellent that combines $A Q$ and a visual cue or $A Q$ and d-pulegone or $A Q$, a visual cue and d-pulegone to provide increased avian repellency to toxic pest baits. $^{76,81}$

Structural application of $A Q$ is a growing field of study. US Patent No. 6328986 B1 involves the use of AQ for deterring birds from perching, roosting or loafing on plant and structural surfaces (supporting information Table S3). ${ }^{85}$ An additional US patent application (No. US14/607 567) describes the use of various quinones to protect building materials from bird, pest and/or fungal damage. ${ }^{86}$

\section{NON-AVIAN APPLICATIONS}

Relatively few studies have evaluated $A Q$ as a mammalian repellent (Table 4; supporting information Table S2). Wild boar (Sus scrofa, L.) cause extensive damage to agricultural crops in the United States and Europe. ${ }^{87,88}$ Santilli et al..$^{89}$ demonstrated the efficacy of $6400 \mathrm{mg} \mathrm{AQ} \mathrm{kg}^{-1}$ as a corn seed treatment with wild boar. In choice testing, AQ reduced wild boar consumption of treated corn by $86.5 \%$. In no-choice testing, AQ reduced wild boar consumption by $40 \% .^{89}$

Several studies have evaluated $\mathrm{AQ}$ repellency in rodents. Anthraquinone has been regularly applied to coniferous and other tree species in direct seeding applications throughout the mid-south of the United States. Although applied primarily as a bird repellent, the effects of $A Q$ as a rodent repellent are unclear. In two field tests, $150000 \mathrm{mg} \mathrm{AQ} \mathrm{kg}^{-1}$ failed to protect loblolly pine seed $^{90}$ and white oak (Quercus alba L.), cow oak (Quercus michauxii Nutt.) and cherrybark oak (Quercus pagoda Raf.) acorns ${ }^{37}$ from bird and rodent damage. Thirteen-lined ground squirrels (Ictidomys tridecemlineatus, Mitchill) damage newly seeded corn. ${ }^{91}$ In field testing of corn treated with $4826 \mathrm{mg} \mathrm{AQ} \mathrm{kg}^{-1}$, thirteen-lined ground squirrels ate similar amounts of AQ-treated and untreated 
corn. ${ }^{12}$ In tests with black-tailed prairie dogs (Cyomys ludovicainus, Ord.), 24-37\% repellency was observed for corn treated with 5000-40000 mg AQ kg-1. Black-tailed prairie dogs consumed more untreated oat baits than any other treatment, including 10000 and $20000 \mathrm{mg} \mathrm{AQ} \mathrm{kg}^{-1}$ treated oat baits and 10000 and $20000 \mathrm{mg} \mathrm{AQ} \mathrm{kg}^{-1}$ plus $20000 \mathrm{mg}$ zinc phosphide $\mathrm{kg}^{-1}$ treated oat baits. ${ }^{73}$ Rodenticide baits (20000 mg zinc phosphide $\mathrm{kg}^{-1}$ ) treated with $10000-20000 \mathrm{mg} \mathrm{AQ} \mathrm{kg}^{-1}$ resulted in $30 \%$ mortality among black-tailed prairie dogs. ${ }^{73}$

In Europe, several tests have been conducted for the protection of agricultural crops from wild rodents, including common voles (Microtus arvalis, Pallas) and house mice (Mus musculus, L.). These studies evaluated the effect of odor on rodent consumption of wheat. Male common voles demonstrated no difference in wheat consumption in the presence of $A Q$, while female common voles exhibited a $47 \%$ reduction in wheat consumption in the presence of $A Q .{ }^{92,93}$ Female house mice demonstrated no difference in consumption of wheat in the presence of $A Q$, while male house mice preferred wheat in the presence of $A Q .{ }^{87,88}$ Feeding trials with Gunther's voles (M. guentheri, Danford \& Alston), Tristram's jirds (Meriones tristrami, Thomas) and Botta's pocket gophers (Thomomys bottae, Eydoux \& Gervais) offered AQ-treated carrots [Daucus carota subsp. sativus (Hoffm.) Schubl. \& G. Martens] and barley (Hordeum vulgare L.) illustrated AQ repellency in Tristram's jirds only. Gunther's voles and pocket gophers consumed similar amounts of AQ-treated and untreated food. ${ }^{94}$

Extensive testing has been conducted in New Zealand to ensure brush-tailed possum (Trichosurus vulpecula, Kerr) and black rat (Rattus rattus, L.) kills remain high when $\mathrm{AQ}$ treatments are used to protect birds. Baits treated with $400-1000 \mathrm{mg} \mathrm{AQ} \mathrm{kg}^{-1}$ generally did not prevent consumption of lethal or non-lethal baits by possums. ${ }^{95-97}$ However, rats (Rattus rattus L.) have demonstrated some repellency for AQ-treated baits and thus decreased mortality in lethal baiting programs. ${ }^{96,97}$

As a biopesticide, natural sources of $A Q$ have been identified as insecticides and insect repellents. For example, the heartwood of teak (Tectona grandis, L.f) is known for its durability against termites owing largely to the presence of various AQs. Osbrink et al..$^{98}$ observed little termiticidal activity of $A Q$ in Formosan subterranean termites (Coptotermes formosanus, Shiraki). Gupta and Sen-Sarma ${ }^{99}$ also evaluated $A Q$ and derivatives of $A Q$ for toxicity to termites (Neotermes bosei and Microcerotermes beesoni). Chrysophanol, an AQ derivative, had the highest termite resistance, while $\mathrm{AQ}$ was only effective at higher doses. ${ }^{99}$

Emodin, an AQ derivative, has been evaluated as a feeding deterrent with eastern tent caterpillars (Malacosoma americana, Fabricius). Trial and Dimond ${ }^{100}$ observed a reduction in feeding by caterpillars on pin cherry branches (Prunus pensylvanica, L.f.) sprayed with a solution of $4 \mathrm{mg}$ of emodin in $1 \mathrm{~mL}$ of chloroform when compared with untreated branches. Emodin can also cause mortality in various mosquito larvae. ${ }^{101,102}$

Several other researchers have conducted insecticidal trials using natural AQs. Ateyyat and Abu-Darwish ${ }^{103}$ conducted laboratory tests using extracts of Sinai buckthorn (Rhamnus dispermus) bark on peach trunk aphid (Pterochloroides persicae). Adult aphids died after a $24 \mathrm{~h}$ exposure to $10000 \mathrm{mg} \mathrm{AQ} \mathrm{kg}^{-1}$ extracts. Ba et al. ${ }^{104}$ also demonstrated insecticidal activity of plant extracts (Cassia nigricans, Vahl) containing AQs on cowpea pod sucking bug (Clavigralla tomentosicollis, Stål), and they recommend use of extracts for controlling cowpea insect pests in Nigeria.

Additional implications of $\mathrm{AQ}$ include feeding deterrence in Dover sole (Solea solea, L.), ${ }^{105}$ other fishes ${ }^{106}$ and ants, ${ }^{107}$ stress reduction in common carp (Cyprinus carpio, L.) $)^{108}$ and reduction in methane gas production in sheep. ${ }^{109}$

\subsection{Discussion}

The extensive use of $A Q$ in diverse areas from insects to wild boar illustrates the many additional uses of this compound beyond avian repellency. Worldwide there is considerable need for rodent and small mammal repellents owing to harvest loss and damage to infrastructure. ${ }^{92}$ Additional testing is needed to evaluate mammalian repellency of AQ-treated agricultural products. Multiple patents exist for feed containing $A Q$ for reduction in stress in fish production (e.g. black carp Mylopharyngodon piceus J. Richardson and Wuchang bream Megalobrama amblycephala P.L. Yih; China Patents No. 101810258 and No. 101810259; 2010).

\section{CONCLUSIONS}

We reviewed more than 100 publications regarding AQ applications for international pest management and agricultural crop protection. Criteria for evaluation of effective chemical repellents include: efficacy, potential for wildlife hazard, phytotoxicity and environmental persistence. As a biopesticide, $A Q$ often meets these criteria of efficacy for the non-lethal management of agricultural depredation caused by pest wildlife. Anthraquinone and its derivatives have been identified as a chemical repellent, perch deterrent, insecticide and feeding deterrent in many wild birds, mammals, insects and fishes.

Research needs for AQ-based products include species-specific efficacy data among all target animals as well as the efficacy of crop-specific applications. This is especially true of rodents and other pest mammal species (i.e. rabbits) that cause millions of dollars of damage to agricultural crops and infrastructure worldwide. ${ }^{110,111}$ Additionally, application strategies are needed to improve the efficacy of foliar $A Q$ applications for the protection of emergent and ripening agricultural crops. For example, the synergistic effect of the addition of an ultraviolet feeding cue to $\mathrm{AQ}$-based repellents is one such tool that may enable registration of AQ-based products for foliar applications. Future research should evaluate this strategy with candidate avian and mammalian species and crops.

Although the mode of action of $A Q$ as a post-ingestive repellent is known, the mechanism behind the emetic nature of $A Q$ in birds and mammals is still unclear. Future research should attempt to elucidate this mechanism. A further understanding of the mode of action of $A Q$ in pest species will enable more reliable use of $A Q$ in pest management.

Because relatively few AQ-based products are currently available for international pest management, cost-benefit analyses would enable the commercial development of necessary non-lethal and insecticidal products. Additional research regarding insect and mammalian repellency and bird-repellent and target-specific pesticides is warranted.

\section{ACKNOWLEDGEMENTS}

This research was partially supported by a Cooperative Research and Development Agreement between Arkion Life Sciences (New Castle, DE) and USDA's National Wildlife Research Center (Fort Collins, CO). Corporate affiliations do not imply endorsement by the US Department of Agriculture. 


\section{SUPPORTING INFORMATION}

Supporting information may be found in the online version of this article.

\section{REFERENCES}

1 Benson AB, Peter Kalm's Travels in North America. Dover Publications Inc., New York, NY (1966).

2 Neff JA and Meanley B, A review of studies on bird repellents. Progress Report 1, Wildlife Research Laboratory, Denver, CO, 15 pp. (1956).

3 Phillips M, The chemistry of anthraquinone. Chem Rev 6:157-174 (1929).

4 Heckmanns F and Meisenheimer M, Protection of seeds against birds. US Patent 2389335 (1944).

5 Avery ML, Humphrey JS and Decker DG, Feeding deterrence of anthraquinone, anthracene, and anthrone to rice-eating birds. $J$ Wildl Manag 61:1359-1365 (1997).

6 Heckmanns F and Meisenheimer M, Bird repellents. German Patent 743517 (1943).

7 Mauldin RE, Primus TM, Volz SA, Kimball BA, Johnston JJ, Cummings JL et al., Determination of anthraquinone in technical material, formulations, and lettuce by high performance liquid chromatography. $J$ Agric Food Chem 50:3632-3636 (2002).

8 Ahmad S, Jabeen F, Khan HA, Samiullah K, Yaqub S, Mubarik MS etal., Effectivness of anthraquinone and methylanthranilate against house sparrow (Passer domesticus) from wheat seeds and seedlings in caged conditions in Pakistan. J Biodivers Environ Sci 6:326-334 (2015).

9 Saleem Z, Ahmad S, Jabeen F, Khan HA, Yaqub S, Samiullah K et al., Efficacy of methylanthranilate and anthraquinone against house crow (Corvus splendens) from maize seeds and seedlings in aviary conditions in Pakistan. J Biodivers Environ Sci 6:435-444 (2015).

10 Handford CE, Elliot CT and Campbell $\mathrm{K}$, A review of the global pesticide legislation and the scale of challenge in reaching the global harmonization of food safety standards. Integr Environ Assess Manag 11:525-536 (2015).

11 Dambach CA and Leedy DL, Ohio studies with repellent materials with notes on damage to corn by pheasants and other wildlife. J Wildl Manag 12:392-398 (1948).

12 Hodne-Fischer EA, Anthraquinone corn seed treatment (Avitec) as a feeding repellent for ring-necked pheasants (Phasianus colchicus) on newly planted corn in Eastern South Dakota. MSc thesis, South Dakota State University, Brookings, SD (2009).

13 Werner SJ, Carlson JC, Tupper SK, Santer MM and Linz GM, Threshold concentrations of an anthraquinone-based repellent for Canada geese, red-winged blackbirds, and ring-necked pheasants. Appl Anim Behav Sci 121:190-196 (2009).

14 Blackwell BF, Helon DA and Dolbeer RA, Repelling sandhill cranes from corn: whole-kernel experiments with captive birds. Crop Prot 20:65-68 (2001).

15 Lacy AE and Barzen JA, Evaluating chemical deterrence at two spatial scales: the effectiveness of chemical deterrence for sandhill cranes in cornfields, in North American Crane Workshop, ed. by Hartup B. Wisconsin Dells, WI, p. 207 (2010).

16 Wright EN, Experiments with anthraquinone and thiram to protect germinating maize against damage by birds. Ann Epiphytol 13:27-31 (1962).

17 Esther A, Tilcher R and Jacob J, Assessing the effects of three potential chemical repellents to prevent bird damage to corn seeds and seedlings. Pest Manag Sci 69:425-430 (2013).

18 Duncan CJ, The response of the feral pigeon when offered the active ingredients of commercial repellents in solution. Ann Appl Biol 51:127-134 (1963).

19 Avery ML, Decker DG and Humphrey JS, Development of seed treatments to control blackbirds. Proc Vertebr Pest Conf 18:354-458 (1998).

20 Avery ML, Humphrey JS, Primus TM, Decker DG and McGrane AP, Anthraquinone protects rice seed from birds. Crop Prot 18:225-230 (1998).

21 Cummings JL, Avery ML, Mathre O, Wilson EA, York DL, Engeman RM et al., Field evaluation of flight control to reduce blackbird damage to newly planted rice. Wildl Soc Bull 30:816-820 (2002).

22 Poche RM, Development of a new bird repellent, Flight Control. Proc Vertebr Pest Conf 18:338-344 (1998).
23 Werner SJ and Provenza FD, Reconciling sensory cues and varied consequences of avian repellents. Physiol Behav 102:158-163 (2011).

24 Neff JA and Meanley B, Bird repellent studies in the eastern Arkansas rice fields. Progress Report 2, Wildlife Research Laboratory, Denver, CO, 22 pp. (1957).

25 Cummings JL, Byrd RW, Eddleman WR, Engeman RM and Tupper SK, Effectiveness of AV-1011 to reduce damage to drill-planted rice from blackbirds. J Wildl Manag 75:353-356 (2011).

26 Werner SJ, DeLiberto ST, Mangan AM, Pettit SE, Ellis JW and Carlson JC, Anthraquinone-based repellent for horned larks, great-tailed grackles, American crows and the protection of California's specialty crops. Crop Prot 72:158-162 (2015).

27 Cummings JL, Pochop PA, Engeman RM, Davis JE, Jr, and Primus TM, Evaluation of Flight Control to reduce blackbird damage to newly planted rice in Louisiana. Int Biodeter Biodegr 49:169-173 (2002).

28 Avery ML, Tillman EA and Laukert CC, Evaluation of chemical repellents for reducing crop damage by Dickcissels in Venezuela. Int J Pest Manag 47:311 - 314 (2001).

29 Werner SJ, Tupper SK, Pettit SE, Ellis JW, Carlson JC, Goldade DA et al., Application strategies for an anthraquinone-based repellent to protect oilseed sunflower crops from pest blackbirds. Crop Prot 59:63-70 (2014).

30 Werner SJ, DeLiberto ST, Pettit SE and Mangan AM, Synergistic effect of an ultraviolet feeding cue for an avian repellent and protection of agricultural crops. Appl Anim Behav Sci 159:107-113 (2014).

31 Werner SJ, Linz GM, Carlson JC, Pettit SE, Tupper SK and Santer MM, Anthraquinone-based bird repellent for sunflower crops. Appl Anim Behav Sci 129:162-169 (2011).

32 Kennedy TF and Connery J, An investigation of seed treatments for the control of crow damage to newly-sown wheat. Ir J Agric Food Res 47:79-91 (2008).

33 Kear J, The reaction of captive mallard to grain treated with a commercial bird repellent. Wildfowl Trust 16:47-48 (1965).

34 Frank VH and Dischner MU, The testing of repellents intended to prevent consumption of seed grain by pheasants. Z Jagdwiss 16:14-22 (1970).

35 Day TD, Clapperton BK, Porter RER, Waas JR and Matthews LR, Responses of free-ranging house sparrows to feed containing primary and secondary repellents. NZ J Crop Hort Sci 40:127-138 (2012).

36 Clapperton BK, Porter RE, Day TD, Waas JR and Matthews LR, Designer repellents: combining olfactory, visual or taste cues with a secondary repellent to deter free-ranging house sparrows from feeding. Pest Manag Sci 68:870-877 (2012).

37 Bollin FS, Direct seeding of red and white oaks in southeastern Louisiana. MSc thesis, Louisiana State University, Baton Rouge, LA (1966).

38 Mann WFJ and Derr HJ, Not for the birds: Morkit, a chemical bird repellent, solves the most difficult problem in direct-seeding longleaf pine. USFS, Washington, DC (1955).

39 Abbott HG, Application of avian repellents to eastern white pine seed. J Wildl Manag 22:304-306 (1958).

40 Evans J, Animal damage and its control in ponderosa pine forests, in Ponderosa Pine: the Species and its Management, ed. by Baumgartner DM and Lotan JE. Washington State University, Pullman, WA, pp. 109-113 (1988).

41 Espelta J, An economic and ecological multi-criteria evaluation of reforestation methods to recover burned Pinus nigra forests in NE Spain. For Ecol Manag 180:185-198 (2003).

42 Gwaze D, Henken D and Johanson M, Direct seeding of shortleaf pine (Pinus echinata Mill.): a review. Forest Research Report No. 5, Missouri Department of Conservation, Jefferson City, MO (2005).

43 Habrouk A, Regeneracion natural y resauracion de la zona afectada por el gran incendio del Bages y Bergueda de 1994. PhD, Universitat Autonoma de Barcelona, Spain (2002).

44 Ordonez JL and Retana J, Early reduction of post-fire recruitment of Pinus nigra by post-dispersal seed predation in different time-since-fire habitats. Ecography 27:449-458 (2004).

45 Defauce $C$ and Enriquez L, Trials with repellents. Bol Serv Plagas For 11:135-136 (1968).

46 Dolbeer RA, Seamans TW, Blackwell BF and Belant JL, Anthraquinone formulation (Flight Control) shows promise as avian feeding repellent. J Wild Manag 62:1558-1564 (1998).

47 Werner SJ, Buchholz R, Tupper SK, Pettit SE and Ellis JW, Functional significance of ultraviolet feeding cues in wild turkeys. Physiol Behav 123:162-167 (2014). 
48 Griffin DN and Baumgartner FM, Evaluation of certain chemicals as bird repellents. Proc Okla Acad Sci 39:78-82 (1959).

49 Tupper SK, Werner SJ, Carlson JC, Pettit SE, Wise JC, Lindell CA et al., European starling feeding activity on repellent treated crops and pellets. Crop Prot 63:76-82 (2014).

50 Werner SJ, Linz G, Tupper SK and Carlson JC, Laboratory efficacy of chemical repellents for reducing blackbird damage in rice and sunflower crops. J Wildl Manag 74:1400-1404 (2010).

51 Schafer EW, Jr, The acute oral toxicity of 369 pesticidal, pharmaceutical and other chemicals to wild birds. Toxicol Appl Pharmacol 21:315-330 (1972).

52 Schafer EW, Jr, Bowles WAJ and Hurlbut J, The acute oral toxicity, repellency, and hazard potential of 998 chemicals to one or more species of wild birds. Arch Environ Contam Toxicol 12:355-382 (1983).

53 Barbee GC, Santer MM and McClain WR, Lack of acute toxicity of an anthraquinone bird repellent to non-target crayfish (Procambarus clarkii) associated with rice-crayfish crop rotations. Crop Prot 29:506-508 (2010).

54 Ballinger KE, Jr, Method for protecting seeds from birds. US Patent 5 885604 (1999).

55 Avery ML, Tillman EA, Humphrey JS, Cummings JL, York DL and Davis JE, Jr, Evaluation of overspraying as an alternative to seed treatment for application of Flight Control bird repellent to newly planted rice. Crop Prot 19:225-230 (2000).

56 Avery ML, Humphrey JS and Tillman EA, Responses of blackbirds to aerial application of Flight Control bird repellent to ratoon rice in Cameron Parish, Louisiana. Proc Temperate Rice Conf 2:321-326 (2002).

57 Avery ML, Whisson DA and Marcum DB, Responses of blackbirds to mature wild rice treated with flight control bird repellent. Proc Vertebr Pest Conf 19:26-30 (2000).

58 Cummings JL, Guarino JL and Knittle CE, Chronology of blackbird damage to sunflowers. Wildl Soc Bull 17:50-52 (1989).

59 Kandel H, Burton J, Deplazes C, Linz G and Santer M, Sunflower treated with Avipel (anthraquinone) bird repellent. 31st National Sunflower Association Research Forum, Fargo, ND (2009).

60 Niner MD, Linz GM and Clark ME, Evaluation of 9,10-anthraquinone application to pre-seed set sunflowers for repelling blackbirds. Hum-Wildl Interact 9:4-13 (2015).

61 York DL, Cummings JL, Engeman RM and Davis JE, Jr, Evaluation of Flight Control and Mesurol as repellents to reduce horned lark (Eremophila alpestris) damage to lettuce seedlings. Crop Prot 19:201-203 (2000)

62 Cummings JL, York DL, Primus TM, Engeman RM and Mauldin $\mathrm{RE}$, Effectiveness of Flight Control to reduce damage to lettuce seedlings from horned larks. Proc Vertebr Pest Conf 22:225-227 (2006).

63 Ayers CR, Moorman CE, Deperno CS, Yelverton FH and Wang HJ, Effects of mowing on anthraquinone for deterrence of Canada geese. J Wildl Manag 74:1863-1868 (2010).

64 Blackwell BF, Seamans TW and Dolbeer RA, Plant growth regulator (Stronghold) enhances repellency of anthraquinone formulation (Flight Control) to Canada geese. J Wildl Manag 63:1336-1343 (1999).

65 Devers P, Reichert P and Poche R, Field trial using Flight Control as a repellent for Canada goose (Branta canadensis) control in Fort Collins, Colorado. Proc Vertebr Pest Conf 18:345-349 (1998).

66 Gordon SE and Lyman N, Flight Control ${ }^{\mathrm{TM}}$ as a grazing repellent for Canada geese at Portland International Airport. Int Bird Strike Comm 25:265-281 (2000).

67 Knauer RFJ, Ballinger KEJ and Gilmore MK, Practical application techniques for Flight Control, a new bird repellent for the aviation industry. Int Bird Strike Comm Eur 25:283-296 (2000).

68 Dunning RA, Bird damage to sugar beet. Ann Appl Biol 76:325-335 (1974).

69 Dieter CD, Warner CM and Ren C, Evaluation of foliar sprays to reduce crop damage by Canada geese. Hum-Wildl Interact 8:139-149 (2014).

70 Carlson JC, Tupper SK, Werner SJ, Pettit SE, Santer MM and Linz GM, Laboratory efficacy of an anthraquinone-based repellent for reducing bird damage to ripening corn. Appl Anim Behav Sci 145:26-31 (2013).

71 Rodriguez EN, Tiscornia G and Tobin ME, Bird depredations in Uruguayan vineyards. Proc Vertebr Pest Conf 21:136-139 (2004).
72 Werner SJ, Ultraviolet strategy for avian repellency. US Patent 9131 678 B1 (2015).

73 Werner SJ, Tupper SK, Pettit SE, Carlson JC and Linz GM, Anthraquinone repellent to reduce take of non-target birds from zinc phosphide rodenticide applications. Appl Anim Behav Sci 135:146-153 (2011).

74 Day TD, Matthews LR and Waas JR, Repellents to deter New Zealand's North Island robin Petroica australis longipes from pest control baits. Biol Conserv 114:309-316 (2003).

75 Clapperton BK, Morgan DKJ, Day TD, Oates KE, Beath AM, Cox NR et al., Efficacy of bird repellents at deterring North Island robins (Petroica australis longipes) and tomtits (P. macrocephala toitoi) from baits. NZ $J$ Ecol 38:116-123 (2014)

76 Day T and Matthews LR, US Patent 2005/0186237 (2005).

77 Crowell M, Booth L, Cowan P, Fairweather A and Westbrooke I, Stability of bird repellents used to protect kea (Nestor notabilis) during aerial 1080 cereal operations. NZ J Ecol 40:42-48 (2016).

78 Cowan $P$, Booth $L$ and Crowell M, Repellents with potential to protect kea and other native birds from aerial poisoning. NZJ Ecol 40:29-41 (2016).

79 Orr-Walker T and Roberts LG, Creative use of captive populations for wildlife conservation. Conservation Management Group ARAZPA NZ Conference, Hamilton, New Zealand (2010).

80 Orr-Walker T, Adams NJ, Roberts LG, Kemp JR and Spurr EB, Effectiveness of the bird repellents anthraquinone and d-pulegone on an endemic New Zealand parrot, the kea (Nestor notabilis). Appl Anim Behav Sci 137:80-85 (2012).

81 Day $T$ and Matthews LR, A bird repellent, International Patent WO 2004/000014 A1 (2003).

82 Damron BL and Jacob JP, Toxicity to poultry of common weed seeds. Fact Sheet PS-55, University of Florida Extension, Gainseville, FL (2001).

83 Sorensen $\mathrm{AE}$, Taste aversion and frugivore preference. Oecologia 53:117-120 (1983).

84 Hilker M and Kopf A, Evaluation of the palatability of chrysomelid larvae containing anthraquinones to birds. Oecologia 100:421-429 (1994).

85 Ballinger KE, Jr, Method of deterring birds from plant and structural surfaces. US Patent 6328986 B1 (2001).

86 Ballinger $\mathrm{KE}$, Jr, Use of quinone compound in building materials. US Patent Application US14/607 561 (2015).

87 Geisser $\mathrm{H}$ and Reyer H-U, Efficacy of hunting, feeding, and fencing to reduce crop damage by wild boars. J Wildl Manag 68:939-946 (2004).

88 Herrero J, Garcia-Serrano A, Couto S, Ortuno VM and Garcia-Gonzales $\mathrm{R}$, Diet of wild boar Sus scrofa L. and crop damage in an intensive agroecosystem. Eur J WildI Res 52:245-250 (2006).

89 Santilli F, Galardi L and Russo C, Corn appetibility reduction in wild boar (Sus scrofa L.) in relationship to the use of commercial repellents. Ann Fac Med Vet 58:213-218 (2005).

90 Langdon OG and LeGrande WP. Rodent depredation - a direct seeding problem. Resarch Note SE-39, USDA Forest Service Southeast Forest Experiment Station, Asheville, NC, pp. 3 (1965).

91 Zurcher NJ, Johnson RJ and Timm RM, Methiocarb and thiram as corn seed repellents for thirteen-lined ground squirrels. Wildl Soc Bull 11:38-42 (1983).

92 Hansen SC, Stolter C and Jacob J, The smell to repel: the effect of odors on the feeding behavior of female rodents. Crop Prot 78:270-276 (2015).

93 Hansen SC, Stolter C and Jacob J, Effect of plant secondary metabolites on feeding behavior of microtine and arvicoline rodent species. J Pest Sci DOI: 10.1007/S10340-015-0723-6 (2016).

94 Hansen S, Stolter C, Baldwin RA, Motro Y, Witmer G and Jacob J, The effect of herbal repellents in five rodent pest species, in Mission Possible: Food for All through Appropriate Plant Protection: XVIII International Plant Protection Congress, Berlin, Germany (2015).

95 Clapperton BK, Day TD, Morgan DKJ, Huddart F, Cox N and Matthews LR, Palatability and efficacy to possums and rats of pest control baits containing bird repellents. NZ J Zool 42:104-118 (2015).

96 Cowan P, Brown S, Forrester G, Booth L and Crowell M, Bird-repellent effects on bait efficacy for control of invasive mammal pests. Pest Manag Sci 71:1075-1081 (2015).

97 Crowell M, Martini M and Moltchanova E, Effect of the addition of bird repellents to aerially applied 1080 baits on rat and possum abundance. NZ J Ecol 40:49-59 (2016). 
98 Osbrink WLA, Tellez MR and Kobaisy M, Assessment of natural products for control of Formosan subterranean termites, in Semiochemicals in Pest and Weed Control, ed. by Petroski RJ, Tellez MR and Behle RW. American Chemical Society, Washington, DC (2003).

99 Gupta BK and Sen-Sarma PK, Antitermite properties of some anthraquinone derivatives. Holzforsch Holzverwert 30:57-58 (1978).

100 Trial HJ and Dimond JB, Emodin in buckthorn: a feeding deterrent to phytophagous insects. Can Entomol 111:207-212 (1979).

101 Georges K, Jayaprakasam B, Dalavoy S and Nair M, Pest-managing activities of plant extracts and anthraquinones from Cassia nigricans from Burkina Faso. Bioresour Technol 99:2037-2045 (2008).

102 Yang Y-C, Lim M-Y and Lee HS, Emodin isolated from Cassia obtusifolia (Leguminosae) seed shows larvicidal activity against three mosquito species. J Agric Food Chem 51:7629-7631 (2003).

103 Ateyyat MA and Abu-Darwish MS, Insecticidal activity of different extracts of Rhamnus dispermus (Rhamnaceae) against peach trunk aphid, Pterochlorides persicae (Homoptera: Lachnidae). Span J Agric Res 7:160-164 (2009).

104 Ba NM, Sawadogo F, Dabire-Binso CL, Drabo I and Sanon A, Insecticidal activity of three plant extracts on the cowpea pod sucking bug, Clavigralla tomentosicollis, Stål (Hemiptera: Coreidae). Pak J Biol Sci 12:1320-1324 (2009).
105 Mackie AM and Mitchell Al, Further studies on the chemical control of feeding behaviour in the dover sole, Solea solea. Comp Biochem Phys A: Mol Integr Physiol 73:89-93 (1982).

106 Rideout JA and Sutherland MD, Pigments of marine animals. XIV. Polyketide sulfates from the crinoid Comatula pectinata. Aust $J$ Chem 34:2385-2392 (1981)

107 Eisner T and Nowicki S, Red cochineal dye (Carminic acid): its role in nature. Science 208:1039-1042 (1980).

108 Xie J, Liu B, Zhou Q, Su Y, He Y, Pan L et al., Effects of anthraquinone extract from rhubarb Rheum officinale Bail on the crowding stress response and growth of common carp Cyprinus carpio var. Jian. Aquaculture 281:5-11 (2008).

109 Kung LJ, Smith KA, Smagala AM, Endres KM, Bessett CA, Ranjit NK et al., Effects of 9,10-anthraquinone on ruminal fermentation, total-tract digestion, and blood metabolite concentrations in sheep. J Anim Sci 81:323-328 (2003).

110 Baldwin RA, Salmon TP, Schmidt RH and Timm RM, Wildlife pests of California agriculture: regional variability and subsequent impacts on management. Crop Prot 46:29-37 (2013).

111 Jacob J and Tkadlec E, Rodent outbreaks in Europe: dynamics and damage, in Rodent Outbreaks: Ecology and Impacts, ed. by Singleton GR, Belmain SR, Brown PR and Hardy B. International Rice Research Institute, Los Baños, Philippines, pp. 207-224 (2010). 